\title{
Improving the Achievement of Learning Indonesian Through the Problem Based Learning Method in SDN 2 Getas
}

\author{
Sumaryati \\ SD Negeri 2 Getas \\ sumaryati@gamil.com
}

\section{Article History}

accepted $14 / 11 / 2020$

approved $21 / 11 / 2020$

published 26/11/2020

\begin{abstract}
The purpose of this study was to increase the interest and learning outcomes of students in the Indonesian language muple in grade III elementary schools with the Problem Based Learning (PBM) learning model. The research conducted was a Classroom Action Research (CAR) in two cycles, with each cycle consisting of one meeting. The stages of each cycle are planning, implementing, observing and reflecting. Each meeting was carried out a pretest and post test to determine the development of students in cycle I 75\% of students who complete after carrying out post tests. In cycle II participants Students who complete after carrying out the post test are $100 \%$. These results indicate that the Problem Based Learning (PBM) learning model can improve student learning outcomes, especially the Indonesian language muple SDN 2 Getas.
\end{abstract}

Keywords: Learning outcomes, problem based learning

\section{Abstrak}

Tujuan dari penelitian ini adalah untuk meningkatkan minat dan hasil belajar peserta didik pada mupel Bahasa Indonesia di sekolah dasar kelas III dengan model pembelajaran Problem Based Learning (PBM). Penelitian yang dilakukan adalah Penelitian Tindakan Kelas (PTK) sebanyak dua siklus, dengan setiap siklusnya terdiri dari satu pertemuan. Tahapan setiap siklusnya adalah perencanaan, pelaksanaan, observasi dan refleksi. Setiap pertemuan dilakukan pretest dan post test untuk mengetahui perkembangan peserta didik.Pada siklus I. Peserta didik yang tuntas setelah melaksanakan post tests sebesar $75 \%$. Pada siklus II peserta Didik yang tuntas setelah melaksanakan post test sebesar $100 \%$. Hasil ini menunjukan bahwa model pembelajaran Problem Based Learning (PBM) dapat meningkatkan hasil belajar peserta didik khususnya mupel Bahasa Indonesia SDN 2 Getas.

Kata kunci: Hasil belajar, pembelajaran berbasis masalah

Social, Humanities, and Education Studies (SHEs): Conference Series https://jurnal.uns.ac.id/shes

p-ISSN 2620-9284

e-ISSN 2620-9292 


\section{PENDAHULUAN}

Sesuai dengan Permendikbud nomor 67 tahun 2013 tentang kurikulum Sekolah Dasar, Kurikulum 2013 bertujuan untuk mempersiapkan manusia Indonesia agar memiliki kemampuan hidup sebagai pribadi dan warga negara yang beriman, produktif, kreatif, inovatif, dan afektif serta mampu berkontribusi pada kehidupan bermasyarakat, berbangsa, bernegara, dan peradaban dunia.Kurikulum 2013 dikembangkan dengan landasan filosofis yang memberikan dasar bagi pengembangan seluruh potensi peserta didik menjadi manusia Indonesia berkualitas yang tercantum dalam tujuan pendidikan nasional.Kurikulum 2013 dikembangkan atas teori "pendidikan berdasarkan standar" (standard-based education), dan teori kurikulum berbasis kompetensi (competency-based curriculum). Pendidikan berdasarkan standar menetapkan adanya standar nasional sebagai kualitas minimal warganegara yang dirinci menjadi standar isi, standar proses, standar kompetensi lulusan, standar pendidik dan tenaga kependidikan, standar sarana dan prasarana, standar pengelolaan, standar pembiayaan, dan standar penilaian pendidikan. Kurikulum berbasis kompetensi dirancang untuk memberikan pengalaman belajar seluas-luasnya bagi peserta didik dalam mengembangkan kemampuan untuk bersikap, berpengetahuan, berketerampilan, dan bertindak.

Dalam pelaksanaan pembelajaran muatan Bahasa Indonesia masih banyak kendala yang muncul. Kendala tersebut antara lain Siswa kurang memperhatikan guru ketika proses belajar mengajar, siswa selalu beranggapan bahwa mata pelajaran Bahasa Indonesia rumit. Minat siswa terhadap mata pelajaran Bahasa Indonesia sangat rendah, siswa hanya mengerjakan latihan soal jika disuruh oleh guru, penggunaan metode ceramah sangat dominan, penggunaan peraga belum menarik bagi siswa. Hal tersebut secara tidak langsung telah mempengaruhi prestasi siswa dari tes formatif materi kelas III SDN 2 GETAS Kec. Kradenan Kabupaten Blora. peneliti mengalami kegagalan karena dari jumlah 8 siswa hanya 2 siswa (25\% ) yang mendapat nilai diatas 75,00 (tuntas) sedangkan 6 siswa (75,00\%) mendapat nilai dibawah KKM

Bertolak dari uraian di atas, maka sebagai jalan keluar peneliti berupaya meningkatkan pembelajaran muatan Bahasa Indonesia ,karena hasil belajar muatan Bahasa Indonesia yang rendah merupakan suatu permasalahan yang harus segera diatasi. Untuk mengatasi masalah tersebut guru harus menciptakan suasana pembelajaran yang menyenangkan. Kegiatan menyenangkan dapat tercipta apabila guru menggunakan metode yang bervariasi dan media yang relevan serta menggunakan pendekatan dan model pembelajaran yang tepat. Dengan demikian siswa akan tertarik mempelajari Bahasa Indonesia dan pembelajaran menjadi lebih bermakna dan tujuan pembelajaran akan tercapai. Dan diharapkan untuk hasil belajar muatan Bahasa Indonesia pada materi dari 7 siswa,80 \% siswa mendapat nilai diatas 75 dan mengalami ketuntasan hasil belajar $100 \%$

\section{METODE}

Penelitian ini dilaksanakan dengan melaksanakan perencanaan yang telah dibuat sebelumnya yakni melaksanakan pembelajaran dengan menggunakan model Problem Based Learning.

Pelaksanaan tindakan penelitian ini direncanakan dalam dua siklus. Siklus pertama dilaksanakan pembelajaran dengan model Problem Based Learning. Siklus kedua dilaksanakan untuk memperbaiki segala sesuatu yang belum baik.

baik pretest maupun post test. Observasi dalam penelitian ini berisi catatan yang menggambarkan bagaimana aktifitas dan hasil belajar siswa dalam pembelajaran materi kewajiban dan hakku yang berkaitan dengan makanan. pada siswa kelas III SDN 2 GETAS Kradenan Blora sebelum menggunakan model Problem Based Learningdan sesudah menggunakan model Problem Based Learning 


\section{HASIL DAN PEMBAHASAN}

Pada siklus pembelajaran dilaksanakan selama dua pertemuan, setiap pertemuan diadakan pretest dan posttest. Untuk mengetahui perkembangan peserta didik selama pembelajaran. Siklus I membahas materi tentang kewajiban dan haakku dirumah berkaitan dengan makanan.Pembelajaran denganmodeIPjBL dilaksanakan dengan 6 langkah PjBL secara berurutan mulai dari menentukan pertanyaan mendasar, merancang proyek, menyusun jadwal, memantau proses proyek, penilaian hasil dan evaluasi pengalaman. Proyek yang dibuat peserta didik adalah menyusun rantai makanan dengan gambar yang tepat. Berikut ini adalah hasil belajar peserta didik pada siklus yang bisa dilihat pada tabel berikut.

Tabel1.Hasil Belajar Peserta Didik Siklus I

\begin{tabular}{|c|c|c|c|c|c|c|c|c|}
\hline \multirow{3}{*}{ Siklus I } & \multicolumn{4}{|c|}{ Pre Test } & \multicolumn{4}{|c|}{ Post test } \\
\hline & \multicolumn{2}{|c|}{$\begin{array}{l}\text { Presdik } \\
\text { Tuntas }\end{array}$} & \multicolumn{2}{|c|}{$\begin{array}{c}\text { Presdik } \\
\text { Belum Tuntas }\end{array}$} & \multicolumn{2}{|c|}{$\begin{array}{l}\text { Presdik } \\
\text { Tuntas }\end{array}$} & \multicolumn{2}{|c|}{$\begin{array}{c}\text { Presdik } \\
\text { Belum Tuntas }\end{array}$} \\
\hline & Jml & $\%$ & Jml & $\%$ & $\mathrm{Jml}$ & $\%$ & $\mathrm{Jml}$ & $\%$ \\
\hline Pertemu & 1 & 12,5 & 7 & 87,5 & 2 & 25 & 46 & 75 \\
\hline Pertemuan 2 & 75 & 20 & 65 & 2 & 6 & 75 & & \\
\hline
\end{tabular}

Berdasarkan table diatas maka terjadi peningkatanan tara pretest dan posttest pada pertemuan 1.Setiap individu peserta didik sudah mengalami peningkatan hasil belajarnya. Peserta didik mengalami peningkatan hasil belajar pada pertemuan 1 . Ketuntasan klasikal juga mengalami peningkatan,pada pretest hanya terdapat 2 anak yang sudah tuntas, tetapi pada post test bertambah menjadi 6 anakyangsudah tuntas dengan Kriteria Ketuntasan Minimal (KKM) sebesar70.Demikian juga pada pertemuan 2 jumlah peserta didik yang sudah tuntas KKM mengalami peningkatan. Pada pretest ada 2 anak yang baru tuntas,sudah meningkat menjadi 6 peserta didik yang tuntas setelah melaksanakan post test. Perbandingan antara hasil posttest pada pertemuan 1 dan pertemuan 2 juga terdapat perbedaan. Pada pertemuan1 peserta didik yang sudah tuntas hanya ada anak,sedangkan pada pertemuan 2 sudah meningkat menjadi 6 anak.Persentase ketuntasan klasikalnya meningkat, jika pertemuan 1 hanya $25 \%$ maka pada pertemuan 2 menjadi $75 \%$.

Berdasarkan refleksi pada siklus I maka diputuskan untuk melanjutkan kesiklus II dikarenakan belum mencapai ketuntasan klasikal yang diharapkan. Siklus II membahas materi tentang Rumah tempat berlindung. Pembelajaran dengan model PjBL dilaksanakan dengan 6 langkah PjBL secara berurutan seperti siklus I Proyek yang dibuat peserta didik adalah membuat kaliamt saran yang tepat.Berikut ini adalah hasil belajar peserta didik pada siklus II yang bias dilihat pada tabel berikut.

Tabel2.Hasil Belajar Peserta Didik SiklusII

\begin{tabular}{|c|c|c|c|c|c|c|c|c|}
\hline \multirow{3}{*}{ Siklus II } & \multicolumn{4}{|c|}{ Pre Test } & \multicolumn{4}{|c|}{ Post test } \\
\hline & \multicolumn{2}{|c|}{$\begin{array}{l}\text { Presdik } \\
\text { Tuntas }\end{array}$} & \multicolumn{2}{|c|}{$\begin{array}{c}\text { Presdik } \\
\text { Belum Tuntas }\end{array}$} & \multicolumn{2}{|c|}{$\begin{array}{l}\text { Presdik } \\
\text { Tuntas }\end{array}$} & \multicolumn{2}{|c|}{$\begin{array}{c}\text { Presdik } \\
\text { Belum Tuntas }\end{array}$} \\
\hline & $\mathrm{Jml}$ & $\%$ & $\mathrm{Jml}$ & $\%$ & $\mathrm{Jml}$ & $\%$ & $\mathrm{Jml}$ & $\%$ \\
\hline Pertemuan 1 & 6 & 75 & 2 & 25 & 6 & 75 & 2 & 25 \\
\hline Pertemuan 2 & 6 & 75 & 2 & 25 & 6 & 75 & 2 & 25 \\
\hline
\end{tabular}

Berdasarkan table diatas maka terjadi peningkatan antara pretest dan posttest pada pertemuan 1.Setiap individu peserta didik sudah mengalami peningkatanhasil belajarnya. Ketuntasan klasikal juga mengalami peningkatan,pada pretest hanya terdapat 2 anak yang sudah tuntas, tetapi pada posttest bertambah menjadi 6 anak 
yang sudah tuntas dengan Kriteria Ketuntasan Minimal (KKM) sebesar 70.Demikian juga pada pertemuan2 jumlah peserta didik yang sudah tuntas KKM mengalami peningkatan.Pada pretest ada 6 anak yang baru tuntas,sudah meningkat menjadi

8 peserta didik yang tuntas setelah melaksanakan posttest. Perbandingan antara hasil posttest pada pertemuan 1 dan pertemuan 2 juga terdapat perbedaan.Pada pertemuan 1 peserta didik yang sudah tuntas hanya ada 6 anak,sedangkan pada pertemuan2 sudah meningkatmenjadi 6 anak.Persentase ketuntasan klasikalnya meningkat, jika pertemuan 1 hanya25 \%makapada pertemuan2menjadi $75 \%$.

Setelah melakukan refleksi pada siklus 2 diputuskan untuk tidak dilanjutkan kesiklus III karena dianggap sudah berhasil yaitu sudajh 75 \% yang memenuhi KKM.

.Hal ini sesuai dengan konsep atau teori yang diungkap oleh Nanang Hanafiah dan Cucu Suhana (2009:30) bahwa langkah penerapan Model pembelajaran ini merupakan model pembelajaran inovatif yang melibatkan kerja proyek dimana peserta didik bekerja secara mandiri. Hasil penelitian ini juga sesua dengan penelitian sebelumnya yang dilakukan olehSurya, dkk (2018) yang membuktikan bahwa model pembelajaran Project Based Learning (PjBL) dapat meningkatkan hasil belajar dan kreativitas peserta didik.

\section{SIMPULAN}

Penerapan model pembelajaran Project Based Learning (PjBL) dapat meningkatkan hasil belajar peserta didik Kelas $\mathrm{V}$ pada mupel IPA materi rantai makanan. Peningkatan yangterjadi karena adanya kesan pembelajaran yang mendalam dari peserta didik tehadap materi yang diajarkan melalui setiap proyek yang dibuat. Peserta didik akan selalu teringat akan mater iyang diajarkan dikarenakan mereka menemukandan membangun sendiri pengetahuan mereka pada saat membuat proyek yang sudah disepakati. Berdasarkan penelitian yang telah dilaksanakan salahsatu model pembelajaran yang harus dikuasai guru adalah PjBL karena model ini sangat cocok digunakan dalam keadaan pandemi seperti ini, apalagi dalam kondisi belajar dari rumah. Peserta didik akan membangun pengetahuannya sendiri dengan proyek yang sudah disepakati. Guru bisa memantau proses selama proyek dilaksanakan dengan bekerjasama dengan orangtua.

\section{DAFTAR PUSTAKA}

Erfrimal, F, dkk. (2017). Penerapan Model Project Based Learning (PjBL) untuk Meningkatkan Kecermatan dan Kreasi Seni Rupa. DIADIK : Jurnal IImiah Teknologi Pendidikan, 7(2). 48-61.

Fitriyati, I, dkk. (2017). Pengembangan Perangkat Pembelajaran IPA untuk Meningkatkan Kemampuan Berpikir Tinggi dan Penalaran IImiah Siswa Sekolah Menengah Pertama. Jurnal Pembelajaran Sains, 4(1). 27-34.

Hanafiah, dan Cucu Suhana. 2009. Konsep Strategi Pembelajaran. Bandung: PT. Refika aditama

Kunandar. 2011. Langkah Mudah Penelitian Tindakan Kelas Sebagai Pengembang Profesi Guru. Jakarta: PT Raja Grafindo Persada.

Miyarso, E. 2019. Perancangan Pembelajaran Inovatif. Jakarta:Kemdikbud. Nurfitriyanti, M. (2016). Mode IPembelajaran Project Based Learning Terhadap Kemampuan Pemecahan Masalah Matematika. Jurnal Formatif, 6(2). 140-160. Prabowo,S.A.(2015).The effective nessof scientific based learning towards science process skill mastery of PGSD students.Jurnal Pendidikan IPA Indonesia, 4(1), 15-19.

Sugandi, A. 2007. Teori Pembelajaran Semarang: UNNES Press.

Sudjana, N. 2009. Penilaian Hasil Proses Belajar Mengajar (Cetakan Ketiga belas). Bandung: PT Remaja Rosdakarya. 
SHEs: Conference Series 3 (3) (2020) $1353-1357$

Surya. A.P, dkk (2018). Penerapan Model Pembelajaran Project Based Learning (PjBL) untuk Meningkatkan Hasil Belajar dan Kreativitas Siswa Kelas III SD Negeri SidojeroLor 01 Salatiga. Jurnal Pesona Dasar, 6(1), 51-54. 